\title{
Italian Consensus Recommendations for the management of hepatitis $C$ infection in patients with rheumatoid arthritis
}

Marco Sebastiani, Laura Milazzo, Fabiola Atzeni, Caterina Vacchi, Andreina Manfredi, Luca Quartuccio, Carlo Scirè, Giovanni Battista Gaeta, Giovanni Lapadula, Orlando Armignacco, Marcello Tavio, Salvatore D'Angelo, Pierluigi Meroni, Laura Bazzichi, Walter Grassi, Alessandro Mathieu, Claudio Mastroianni, Evangelista Sagnelli, Teresa Santantonio, Caterina Uberti Foppa, Massimo Puoti, Loredana Sarmati, Paolo Airò, Oscar Massimiliano Epis, Rossana Scrivo, Miriam Gargiulo, Agostino Riva, Giovanni Ciancio, Gianguglielmo Zehender, Gloria Taliani, Luca Meroni, Salvatore Sollima, Piercarlo Sarzi-Puttini \& Massimo Galli

To cite this article: Marco Sebastiani, Laura Milazzo, Fabiola Atzeni, Caterina Vacchi, Andreina Manfredi, Luca Quartuccio, Carlo Scirè, Giovanni Battista Gaeta, Giovanni Lapadula, Orlando Armignacco, Marcello Tavio, Salvatore D’Angelo, Pierluigi Meroni, Laura Bazzichi, Walter Grassi, Alessandro Mathieu, Claudio Mastroianni, Evangelista Sagnelli, Teresa Santantonio, Caterina Uberti Foppa, Massimo Puoti, Loredana Sarmati, Paolo Airò, Oscar Massimiliano Epis, Rossana Scrivo, Miriam Gargiulo, Agostino Riva, Giovanni Ciancio, Gianguglielmo Zehender, Gloria Taliani, Luca Meroni, Salvatore Sollima, Piercarlo Sarzi-Puttini \& Massimo Galli (2018): Italian Consensus Recommendations for the management of hepatitis $C$ infection in patients with rheumatoid arthritis, Modern Rheumatology, DOI: 10.1080/14397595.2018.1558918

To link to this article: https://doi.org/10.1080/14397595.2018.1558918 


\section{MORH-D-18-00446 Received: 15-Oct-2018; Accepted: 5-Dec-2018}

\section{$\underline{\text { Review Article }}$}

Italian Consensus Recommendations for the management of hepatitis $\mathrm{C}$ infection in patients with rheumatoid arthritis

Running title: Management of hepatitis C infections in RA

Marco Sebastiani ${ }^{1}$, Laura Milazzo ${ }^{2}$, Fabiola Atzeni $^{3}$, Caterina Vacchi ${ }^{1}$, Andreina Manfredi ${ }^{1}$, Luca Quartuccio $^{4}$, Carlo Scirè ${ }^{5}$, Giovanni Battista Gaeta ${ }^{6}$, Giovanni Lapadula ${ }^{7}$, Orlando Armignacco ${ }^{8}$, Marcello Tavio ${ }^{9}$, Salvatore D’Angelo $^{10}$, Pierluigi Meroni ${ }^{11}$, Laura Bazzichi ${ }^{12}$, Walter Grassi ${ }^{13}$, Alessandro Mathieu ${ }^{14}$, Claudio Mastroianni ${ }^{15}$, Evangelista Sagnelli ${ }^{16}$, Teresa Santantonio ${ }^{17}$, Caterina Uberti Foppa ${ }^{18}$, Massimo Puoti ${ }^{19}$, Loredana Sarmati $^{20}$, Paolo Airò ${ }^{21}$, Oscar Massimiliano Epis ${ }^{22}$, Rossana Scrivo ${ }^{23}$, Miriam Gargiulo ${ }^{24}$, Agostino Riva ${ }^{3}$, Giovanni Ciancio ${ }^{25}$, Gianguglielmo Zehender ${ }^{26}$, Gloria Taliani ${ }^{15}$, Luca Meroni ${ }^{3}$, Salvatore Sollima ${ }^{3}$, Piercarlo Sarzi-Puttini ${ }^{2}$, and Massimo Galli ${ }^{3}$

${ }^{1}$ Rheumatology Unit, Department of Medical and Surgical Science, University of Modena, Azienda Policlinico of Modena, Italy; ${ }^{2}$ Infectious Diseases Unit, University of Milano, Luigi Sacco Hospital, Milan, Italy; ${ }^{3}$ Rheumatology Unit, L. Sacco University Hospital, Milan, Italy; ${ }^{4}$ Department of Medical and Biological Sciences, Rheumatology Clinic, University of Udine, Udine, Italy; ${ }^{5}$ Epidemiology Unit, Italian Society for Rheumatology (SIR), Milan, Italy; ${ }^{6}$ Infectious Diseases and Viral Hepatitis Unit, Department of Internal and Specialistic Medicine, Second University of Naples, Naples, Italy; ${ }^{7}$ Department of Medicine - Rheumatology Unit, Medical School, University of Bari, Bari, Italy; ${ }^{8}$ Infectious Disease Unit, Belcolle Hospital, Viterbo, Italy; ${ }^{9}$ Unit of Emerging and Immunosuppressed Infectious Diseases, Department of Gastroenterology and Transplantation, Azienda Ospedaliero-Universitaria "Ospedali Riuniti", Torrette Ancona, Italy; ${ }^{10}$ Rheumatology Department of Lucania, San Carlo Hospital of Potenza and Madonna delle Grazie Hospital of Matera, Potenza, Italy; ${ }^{11}$ Division of Rheumatology, Department of Clinical Sciences and Community Health, Gaetano Pini Orthopedic Institute, University of Milan, Milan, Italy; ${ }^{12}$ Rheumatology Unit, Department of Clinical and Experimental Medicine, University of Pisa, Pisa, Italy; ${ }^{13}$ Department of Rheumatology, Università Politecnica 
delle Marche, Ospedale "C. Urbani", Jesi Ancona, Italy; ${ }^{14}$ Rheumatology Unit, University Clinic and AOU of Cagliari, Cagliari, Italy; ${ }^{15}$ Infectious Diseases Unit, Department Public Health and Infectious Disease, "Sapienza" University of Rome, Rome, Italy; ${ }^{16}$ Department of Mental Health and Public Medicine, Second University of Naples, Naples, Italy; ${ }^{17}$ Clinic of Infectious Diseases, University of Foggia, Foggia, Italy; ${ }^{18}$ Department of Infectious Diseases, San Raffaele Scientific Institute, Università Vita-Salute, Milan, Italy; ${ }^{19}$ Department of Infectious Diseases, AO Niguarda Ca' Granda, Milano, Italy; ${ }^{20}$ Clinical Infectious Diseases, Tor Vergata University, Rome, Italy; ${ }^{21}$ Rheumatology and Clinical Immunology Unit, Spedali Civili of Brescia, Brescia, Italy; ${ }^{22}$ Rheumatology Unit, A.O. Ospedale Niguarda Cà Granda, Milan, Italy; ${ }^{23}$ Department of Internal Medicine and Medical Specialties-Rheumatology Unit, Sapienza University of Rome, Rome, Italy; ${ }^{24}$ Third Department of Infectious Diseases- D. Cotugno Hospital- AORN dei Colli, Naple, Italy; ${ }^{25}$ Rheumatology Unit, Department of Medical Sciences, University of Ferrara and Sant'Anna University Hospital, Ferrara, Italyl; ${ }^{26}$ Chair of Hygiene, University of Milan, Milano, Italy

18 pages

2 tables; We desire color reproduction for table 2.

Keywords: Consensus; Hepatitis C; Management; Rheumatoid arthritis; Treatment

Corresponding author: Marco Sebastiani,

Rheumatology Unit, Department of Medical and Surgical Sciences, University of Modena and Reggio Emilia,

Via del Pozzo, 71, 41121, Modena, Italy

Tel +39-059-4222595, Fax +39-059-4223007, E-mail: marco.sebastiani@unimore.it

Running title: Management of hepatitis C infections in RA 


\section{Abstract}

Objectives. The recent itroduction of direct-acting antiviral agents (DAAs) which can eliminate Hepatitis C virus (HCV) had revoluzionized the treatment of $\mathrm{HCV}$ infections also in a complex clinical setting such as the patients with rheumatoid arthritis (RA). HCV elimination is also opportune due to the availability of more efficient immunosuppressive drugs, whose effect on the course of HCV infection is largely unknown.

Methods. Consensus process was endorsed by the Italian Society of Rheumatology (SIR) and the Italian Society of Infectious and Tropical Diseases (SIMIT) to review the available evidences and produce practical, hospitalwide recommendations. The consensus panel consisted of 18 infectious diseases consultants, 20 rheumatologists and one clinical epidemiologist, who used the criteria of the Oxford Centre for Evidence-based Medicine to assess the quality of the evidences and the strength of their recommendations.

Results. A core-set of statements about management of patients with RA and infection by HCV have been developed to help clinicians in their clinical practice.

Conclusions. A screening for HCV should be performed in all RA patients and it is mandatory before starting an immunsuppressive therapy. Finally, a DAA treatment should be considered in all HCV-infected patients.

\section{Significance and Innovations.}

- $\mathrm{HCV}$ antibodies should be investigated at the time of diagnosis of RA and, in any case, before starting immunosuppressive therapy with disease modifying antirheumatic drugs (DMARDs).

- $\quad \mathrm{HCV}$ eradication with DAA should be attempted as soon as possible, depending on patient conditions allowing a continuous oral treatment lasting 8-12 weeks

- $\quad$ Conventional and biological DMARDs are allowed in patients with HCV infection, but they should be used cautiously in presence of advanced liver disease.

\section{Introduction}

Hepatitis C virus (HCV) infection is worldwide a major cause of liver cirrhosis and hepatocellular carcinoma. The 2015 estimated global prevalence of viraemic HCV infection was 1\%, corresponding to about 71.1 million HCV infected subjects, with wide regional differences, showing lower prevalence in North-Western Europe and North America and higher prevalence in Central and Eastern Asia, Eastern Europe and North Africa [1,2]. In 
Italy the viraemic HCV infection prevalence would be about $1.1 \%$ [1], even if this estimate is controversial and rapidly decreasing after the treatment with direct-acting antiviral agents (DAAs) of over 148,000 cases [3].

The estimated prevalence of rheumatoid arthritis (RA) in Italy is $0.41 \%$ [4] and, although some evidences suggested a positive association with chronic HCV infection [5-7], data are conflicting and the relationship still uncertain [8-10]. Chronic stimulation of B lymphocytes by HCV can lead to the production of polyclonal IgG, cryoglobulins and rheumatoid factor, generating HCV-induced inflammatory arthritisis, which features overlaps with those of RA that can complicate the achievement of a differential diagnosis [11]. It is also probable that, due to their age and the frequency of hospitalizations, among patients with RA there is a part of the HCV infections not yet diagnosed in the country.

In a study of the Veterans Affairs Rheumatoid Arthritis Registry [12] RA patients with concomitant HCV have higher disease activity scores, they were more likely to be treated with prednisone and TNF- $\alpha$ inhibitors (TNFi) therapies and less likely to receive methotrexate (MTX) compared to HCV-negative patients. Moreover, either HCV infection and RA have been associated with an increased risk of lymphoproliferative disorders, particularly B-cells non-Hodgkin's lymphomas [13, 14]. Despite this, a screening for HCV of all patients with early arthritis is not universally accepted, even thought it is considered mandatory before starting any immunosuppressive or hepato-toxic treatment [15-17]. The recent introduction of new antiviral agents and interferon-free regimens has revolutionised the treatment of patients with $\mathrm{HCV}$ infection, leading to high rates of sustained virological response with a high safety profile, making it possible to eliminate the virus after a relatively short treatment even in patients suffering from chronic diseases that compromise the immune system [18].

On the basis of all of the above, there is a need for clear recommendations concerning diagnosis and treatment of hepatitis $\mathrm{C}$ infections in patients with $\mathrm{RA}$, as well as indications concerning the post- antiviral treatment resumption of disease modifying antirheumatic drugs (DMARDs). For this reason, the Italian Society of Rheumatology (SIR) and the Italian Society of Infectious and Tropical Diseases (SIMIT) endorsed a national consensus process to review the available evidences and to produce practical, hospital-wide recommendations.

\section{Methods}

The recommendations for the management of RA patients with HCV infection included in this paper are the product of a consensus procedure performed by the Italian group for the Study and Management of the Infections in patients with Rheumatic diseases (ISMIR group), promoted by the Italian Society of Rheumatology (SIR) and the Italian Society of Infectious and Tropical Diseases (SIMIT). 
The consensus panel that was set up for this purpose consisted of infectious disease consultants, rheumatologists and epidemiologists who used the criteria of the Oxford Centre for Evidence-based Medicine [19] to assess the quality of the evidence and the strength of their recommendations.

We considered systematic reviews or observational studies, or case reports evaluating the risk of hepatitis infections or reacutization in patients exposed to biological DMARDs (bDMARDs).

\section{Search strategy}

In order to be included, the studies had to be systematic reviews or observational studies (i.e. cross-sectional, non-interventional case-control or cohort studies), or case reports evaluating the risk of HCV infection or reacutization in patients exposed to bDMARDs. The MEDLINE and EMBASE databases were searched for articles published between 1998 and December 2015 using the key words: "rheumatoid arthritis" or "arthritis" or "arthritides" or "polyarthritis" and "anti- tumor necrosis factor (TNF) drugs" or "anti-TNF agents" or "anti-TNF therapy" or "TNF inhibitors" or "anti-TNF blockers" or "infliximab" or "etanercept" or "adalimumab" or "certolizumab" or "golimumab" or "tocilizumab" or "abatacept" or "rituximab" or "direct-Acting antiviral agents" and "hepatitis C infections" or "HCV infection". There were no restrictions on publication status or language.

\section{Inclusion/exclusion criteria}

The participants of selected the studies had to be diagnosed as having RA on the basis of the 1987 or 2010 criteria $[20,21]$. Studies including subjects aged $<18$ years were discarded in order to prevent the inclusion of patients with juvenile-onset RA or psoriatic arthritis (PsA). The observed populations had to be representative of the general population of RA patients, and the prevalence of hepatitis infections in RA patients treated with biological or non biological DMARDs had to be reported.

\section{HCV, conventional DMARDS and steroids}

Conventional DMARDs (cDMARDs), such as MTX or leflunomide (LEF), are potentially hepatotoxic and, of consequence, they may be less frequently prescribed in patients affected by chronic hepatitis C [22]. Conversely, only small or retrospective studies suggest safety and tolerability of traditional and bDMARDs in these patients $[23-25]$ 
Furthermore, the risk of MTX-related hepatotoxicity, in particular liver cirrhosis, appears to be lower in RA patients than in patients presenting PsA [26].

Despite the weakness of the evidences, the 2015 American College of Rheumatology (ACR) recommendations for RA treatment suggested the same treatments in RA patients with or without HCV infection, the former to be strictly monitored for aminotransferases (every 2-4 weeks for the first 3 months after MTX, LEF, and sulfasalazine (SSZ) initiation, and every 8-12 weeks thereafter) and to be considered for antiviral therapy [27]. In this regard, Burton et al. described the highest risk of hepatotoxicity events during the first 6 months after DMARDs initiation [25].

Few data are available regarding the risk of $\mathrm{HCV}$ reactivation in patients undergoing glucocorticoid therapy. The immunosuppressive effects of glucocorticoids is known and in literature there are some case of HCV reactivation described [Sciascia S 2017, ChenMH 2015, Mori N ]. Although enhanced HCV replication is relatively common in HCV-infected patients treated with chemotherapy or immunosuppressive therapy, it does not lead to serious sequelae [Lee HL 2017].

\section{HCV and biological drugs}

TNF- $\alpha$ inhibitors $(\boldsymbol{T N F i})$. TNFi have been used to treat patients with chronic inflammatory arthropaties and HCV infection since 1999 [28]. Although the majority of studies show that TNFi are well tolerated in HCVinfected patients with RA or other rheumatic diseases [29], the lack of long-term, controlled clinical trials makes it difficult to achieve a definitive statement on the safety of TNFi therapies for RA in the setting of chronic hepatitis $\mathrm{C}$.

Nevertheless, despite a safety warning raised in 2004 by the Food and Drug Administration (FDA) about the risk of severe hepatotoxicity of infliximab [30], none of the events reported occurred in patients with HCV hepatitis and an elevation of liver enzymes or raise of $\mathrm{HCV}$ viral load were reported in less than $10 \%$ of $\mathrm{HCV}$ infected patients affected by RA [29].

More recently, Iannone et al randomized in a prospective clinical trial $29 \mathrm{HCV}$ infected subjects with RA, 13 receiving etanercept alone, 9 MTX alone and 7 a combination therapy with etanercept and MTX. During 1-year follow-up, 5 patients discontinued the treatment because of inefficacy or adverse events other than hepatotoxicity. Among the remaining subjects, no differences in hepatotoxicity were found among the 3 arms [31]. Ko-Ming Lin et al retrospectively evaluated, for a 12 month-period, 20 patients affected by RA and HCV 
who underwent TNFi treatment (18 etanercept and 2 adalimumab), 16 of them in combination with MTX. The rate of hepatotoxicity was the same of a series of 81 RA patients without HCV infection [32].

There are limited data available about long-term safety of TNFi drugs in patients presenting chronic hepatitis C. The effect of this kind of immunosoppression on host immunity against HCV is poorly known and there's the possibility of immune mediated liver damage induced by the inhibition of TNF- $\alpha$, even if the incidence of these reactions appears to be very low [33].

Yi-Ming Chen et al retrospectively described 20 RA patients with chronic hepatitis C treated with TNFi drugs (12 received etanercept, 6 adalimumab and 2 golimumab) for a mean period of $23.4 \pm 13.7$ months. No hepatotoxicity occurred in the studied population [34]. Conversely, Gandhi NP et al in a long-term retrospective study on 14 patients who received etanercept for RA and psoriatic arthritis reported an elevation of aminotransferases in 7 out of 14 patients over a median follow-up of 105 months. In two of them a concomitant increase of HCV-RNA was observed [35].

Finally, Temel $\mathrm{T}$ et al reported one episode of $\mathrm{HCV}$ reactivation in a case series of 7 patients with autoimmune diseases and chronic HCV infection, who received TNFi drugs for a minimum of 36 months [36].

TNF- $\alpha$ may play a divergent role in chronic hepatitis C. Serum levels of TNF- $\alpha$ correlate with serum transaminase levels, histological activity and fibrosis, but not with serum HCV RNA levels.

Moreover, $\mathrm{HCV}$ core protein seems to able to inhibit the TNF- $\alpha$-mediated apoptotic signaling pathway, increasing the HCV replication. Therefore, a further suppression of TNF- $\alpha$ might result in a more efficient viral replication and more progressive chronic HCV infection [33].

Conversely, since other studies have showed that the baseline overexpression of TNF- $\alpha$ correlated with a reduced response rate to IFN- $\alpha$ [37-39], Zein et al. [40] conducted a randomized, controlled trial, showing the efficacy of etanercept as adjuvant therapy to IFN- $\alpha$ and postulating a role of etanercept in the restoration of TNF-induced CD4+ cell impairment.

However, although the safety of TNFi in HCV infected patients seems to be acceptable, the long-term influence of the inhibition of the TNF $\square$ on HCV replication is not clearly defined.

Rituximab (RTX). RTX has been widely used to treat B-cell lymphomas and HCV-related mixed cryoglobulinemia (MC) showing an acceptable safety profile [41], although an increase in HCV-RNA levels has been reported in small case series $[34,42]$. Nevertheless, due to the lack of valuable studies, the ACR guidelines 
advise against RTX use in patients with Child-Pugh class B and C liver disease [27]. Very few data are available on the use of anti-CD20 therapy for the treatment of RA in HCV-infected patients.

In the above mentioned study of Yi-Ming Chen et al 6 patients underwent RTX treatment [34]. The mean duration of therapy was $25.8 \pm 16.7$ months. At the end of the treatment no patients showed significant differences in terms of alanine aminotransferase (ALT) and HCV viral activity in comparison to baseline values but, between RTX subjects, HCV viral load increased at the end of follow-up, unlike that in patients treated with TNFi. RTX patients were older, treated for longer period of time, but less likely to receive MTX than TNFi patients. Old age and prolonged immunosuppression were considered predictor of an impair host immunity against $\mathrm{HCV}$ [34].

Tocilizumab and Abatacept. Tocilizumab (TCZ) is a recombinant humanized monoclonal antibody that acts as an interleukin-6 (IL-6) receptor antagonist. It is approved in Europe for the treatment of active RA in patients with inadequate response or intolerance to DMARDs [43].

The safety of TCZ in patients affected by chronic hepatitis $\mathrm{C}$ is poorly known and has been described in few case reports [44-49]. Although drug-induced immunosuppression might be harmful, a beneficial effect may be expected from the inhibition of IL-6 pathway, since high IL6 -serum levels in HCV infected patients cause more liver inflammation and increased hepatocarcinoma (HCC) risk [45, 50]. The experience with TCZ in the course of HCV infection is limited to anedoctal descriptions, however, apart from case of HCV reactivation [48], TCZ safety profile seems to be acceptable.

Abatacept is the first biological immuno-therapy designed to block a process known as T-cell costimulation. Up to date very few data are available in HCV patients and abatacept resulted safe in two cases of RA patients with HCV infection [51].

\section{Targeted synthetic DMARDs.}

Recently, a new class of DMARDs has been introduced for the treatment of RA $[52,53]$. No data are available about a possible influence of these drugs in the HCV infection outcome. Anyway, in in-vitro culture models with human cells, tofacitinib counteracted the suppressive effects of IFN $\alpha$ on viral replication, explaining the possible increased viral infection rates observed during tofacitinib treatment [54].

Summary data of safety and recommendations of c- and b-DMARDs are reported in table $1[25,27,29,40,43$, $46-48,51,54-72]$ 
Finally, a large retrospective study on the US Veterans cohort analyzed 748 patients affected by RA and concomitant HCV infection over a period of 12 months from DMARDs initiation. A total of 640 cDMARDs and 457 bDMARDs treatments (namely, abatacept 22, RTX 28 and TNFi 407, mostly etanercept and adalimumab) were prescribed. Overall, a low rate of hepatotoxicity was observed and the elevation of ALT values occurred more frequently among biologic than non-biologic treatment episodes ( $4.8 \%$ vs $2.3 \%, \mathrm{p}=0.03$ ), although most of biologic regimens were in combinations with non-biologic DMARDs. Most of the episodes occurred in the first 6 months of the treatment (all cases were identified by an increase in ALT $\geq 100 \mathrm{IU} / \mathrm{l}$ ), while no HCV reactivation were observed. All patients with hepatotoxicity recovered their previous status after discontinuation of drugs [25].

\section{Direct-Acting Antiviral Agents in patients with RA and HCV infection}

Treatment of HCV with IFN-based regimens was often unfeasible in rheumatologic patients because of the risk of exacerbation of autoimmune and rheumatic diseases. The advent of the direct-acting antiviral agents (DAAs) represents a new era for the treatment of HCV-related rheumatic disorders. Currently, no data are available about the use of DAAs in HCV-infected RA patients, even if in mixed cryoglobulinemia vasculitis, they showed a very safe profile, particularly with ribavirin-free associations [73-76]. Due to the positive association between RA and HCV infection reported by some authors [5, 10], an attempt to eradicate HCV infection in RA patients would be desirable to reduce the risk of liver damage progression as well as other immunological complications related to HCV infection.

Only few data on concomitant therapy with DMARDs and DAAs are available and, although a good safety profile emerged, the potential risk of pharmacological interactions should be considered before prescribing drug combinations with DAAs. Table 2 shows the potential interactions between currently recommended DAAs and DMARDs, as retrieved from University of Liverpool drug interaction website http://www.hepdruginteractions.org/.

\section{Implementation plan}

The SIR and SIMIT scientific societies plan to perform a national survey on the prevalence of HCV viremic infection in RA patients in Italy and to investigate the outcome of DAA treatment in HCV-infected RA patients. 


\section{Discussion and conclusions}

Due to the mean age and the frequency of hospitalizations of patients with RA, it is probable that the prevalence of chronic HCV infection is higher in the patients suffering from this disease than in the general population. Therefore, according the opinion of the participants to this consensus, HCV should be screened in all the patients with RA and is mandatory before starting an immunsuppressive therapy. Considering the potential risk of HCV reactivation, the negative influence of $\mathrm{HCV}$ infection on clinical course of RA and viceversa (12-14), the consensus participants believe that it is appropriate to treat patients with RA in which HCV infection is known as soon as possible with DAA and to reconsider the possibility of treatment in all cases where the contingent conditions have suggested postponing it.

According to the literature data, RA treatment should not be different in patients with and without HCV infection. The Voting Panel recommended that rheumatologists collaborate with infectious disease specialists or hepatologists in recommending individualized treatment based on other comorbidities, reason(s) for not receiving $\mathrm{HCV}$ treatment, and the need to minimize immunosuppression, and consider using DMARDs other than MTX or LEF, such as SSZ or HCQ.

\section{Statements}

1. HCV antibodies should be investigated at the time of diagnosis of RA and, in any case, before starting immunosuppressive therapy with DMARDs (2B). HCV RNA should be tested in all HCV antibodypositive patients, as well as in antibody-negative patients with cinical or laboratory evidence or a history of liver disease. (2B)

2. According to the international guidelines for the treatment of HCV-related liver disease, the eradication of HCV should be considered in all infected RA patients. Whenever possible in patients with RA, HCV eradication should be attempted before treatment with DMARDs and biological drugs. Treatment with DAA is not incompatible with concomitant treatment with biological agents. (5E).

3. Conventional DMARDs are allowed in patients with HCV infection, but they should be used cautiously, depending on the severity of liver damage (3C). (see table 1). Anti-TNF $\alpha$ drugs are generally safe and well tolerated in patients with concomitant $\mathrm{HCV}$ infection (2B). The safety profile of RTX is good in RA patients, but its use is contraindicated in the presence of Child-Pugh class B and C chronic HCV infection (3C). 
4. Long-term, low-dose daily glucocorticoid administration ( $<10 \mathrm{mg}$ prednisone equivalent) has a significant negative impact on the risk of serious infections, and can negatively affect the evolution of chronic HCV infection (5C).

5. Data about long-term safety of biologic DMARDs are not conclusive. Therefore, a careful monitoring of the liver function and HCV-RNA should be recommended in all patients in which treatment with DAA is not possible or should be postponed (3C).

\section{Conflict of interest: None}

\section{References}

1. Polaris Observatory HCV Collaborators. Global prevalence and genotype distribution of hepatitis C virus infection in 2015: a modelling study. Lancet Gastroenterol Hepatol 2017,2:161-176.

2. Alberti A, Lacoin L, Morais E, Lefevre C, Abogunrin S, Iheanacho I. A literature review of the distribution of hepatitis C virus genotypes across Europe. J Med Virol. 2016,88:2157-2169

3. Aggiornamento dati Registri AIFA DAAs - Epatite C cronica 27 Agosto 2018

4. Rossini M, Rossi E, Bernardi D, Viapiana O, Gatti D, Idolazzi L, Caimmi C, Derosa M, Adami S. Prevalence and incidence of rheumatoid arthritis in Italy. Rheumatol Int. 2014,34:659-64.

5. Su F-H, Wu C-S, Sung F-C, Chang S-N, Su C-T, Shieh Y-H, et al. Chronic hepatitis C virus infection is associated with the development of rheumatoid arthritis: a nationwide population-based study in taiwan. PLoS One 2014 doi: 10.1371/journal.pone.0113579

6. D'amico E, Palazzi C, Fratelli V, Matteo LD, Girolamo GD, Consoli G. High prevalence of hepatitis C virus infection in patients with rheumatoid arthritis. J Clin Rheumatol 1996,2:233.

7. Hsu FC, Starkebaum G, Boyko EJ, Dominitz JA. Prevalence of rheumatoid arthritis and hepatitis C in those age 60 and older in a US population based study. J Rheumatol 2003,30:455-8.

8. Ferucci ED, Choromanski TL, Varney DT, Ryan HS, Townshend-Bulson LJ, McMahon BJ, et al. Prevalence and correlates of hepatitis C virus-associated inflammatory arthritis in a population-based cohort. Seminars in Arthritis and Rheumatism 2017,47:445-450.

9. Cacoub P, Renou C, Rosenthal E, Cohen P, Loury I, Loustaud-Ratti V, et al. Extrahepatic manifestations associated with hepatitis $\mathrm{C}$ virus infection. A prospective multicenter study of 321 patients. Medicine (Baltimore) 2000,79:47-56. 
10. Kudaeva FM, Speechley MR, Pope JE. A systematic review of viral exposures as a risk for Rheumatoid arthritis. Semin Arthritis Rheum. 2018 doi:10.1016/j.semarthrit.2018.03.011.

11. Ramos-Casals M, Muñoz S, Medina F, Jara LJ, Rosas J, Calvo-Alen J, et al. Systemic autoimmune diseases in patients with hepatitis C virus infection: characterization of 1020 cases (The HISPAMEC Registry). J Rheumatol. 2009; 36: 1442-8

12. Patel R, Mikuls TR, Richards JS, Kerr G, Cannon GW, Baker JF. Disease characteristics and treatment patterns in veterans with rheumatoid arthritis and concomitant hepatitis C infection. Arthritis Care Res 2015,67:467-74.

13. Mercer LK, Regierer AC, Mariette X, Dixon WG, Baecklund E, Hellgren K et al. Spectrum of lymphomas across different drug treatment groups in rheumatoid arthritis: a European registries collaborative project. Ann Rheum Dis. 2017,76:2025-2030.

14. Ferri C, Sebastiani M, Giuggioli D, Colaci M, Fallahi P, Piluso A, et al. Hepatitis C virus syndrome: A constellation of organ- and non-organ specific autoimmune disorders, B-cell non-Hodgkin's lymphoma, and cancer. World J Hepatol. 2015,7:327-43

15. Varache S, Narbonne V, Jousse-Joulin S, Guennoc X, Dougados M, Daurès JP, et al. Is routine viral screening useful in patients with recent-onset polyarthritis of a duration of at least 6 weeks? Results from a nationwide longitudinal prospective cohort study. Arthritis Care Res. 2011,63:1565-70

16. Ansemant T, Ornetti P, Garrot JF, Pascaud F, Tavernier C, Maillefert JF. Usefulness of routine hepatitis C and hepatitis B serology in the diagnosis of recent-onset arthritis. Systematic prospective screening in all patients seen by the rheumatologists of a defined area--brief report. Joint Bone Spine. 2012,79:268-70

17. Sebastiani M, Giuggioli D, Colaci M, Fallahi P, Gragnani L, Antonelli A, et al. HCV-related rheumatic manifestations and therapeutic strategies. Curr Drug Targets. 2017,18:803-810.

18. Cacoub P, Commarmond C, Sadoun D, Desbois AC. Hepatitis C Virus Infection and Rheumatic Diseases: The Impact of Direct-Acting Antiviral Agents. Rheum Dis Clin North Am. 2017;43:123-132

19. Oxford Centre for Evidence-based Medicine - Levels of Evidence. 2009. http://www.cebm.net/index.aspx?o=1025 (25 August 2018, date last accessed).

20. Arnett FC, Edworthy SM, Bloch DA, McShane DJ, Fries JF, Cooper NS, et al. The American Rheumatism Association 1987 revised criteria for the classification of rheumatoid arthritis. Arthritis Rheum $1988,31: 315-24$ 
21. Aletaha D, Neogi T, Silman A, Funovits J, Felson D, Bingham CO 3rd, et al. 2010 Rheumatoid Arthritis Classification Criteria: An American College of Rheumatology / European League Against Rheumatism Collaborative Initiative. Arthritis Rheum 2010,62:2569-81

22. Curtis JR, Beukelman T, Onofrei A, Cassell S, Greenberg JD, Kavanaugh A, et al. Elevated liver enzyme tests among patients with rheumatoid arthritis or psoriatic arthritis treated with methotrexate and/or leflunomide. Ann Rheum Dis 2010,69:43-7

23. Tilling L, Townsend S, David J. Methotrexate and hepatic toxicity in rheumatoid arthritis and psoriatic arthritis. Clin Drug Investig 2006,26:55-62.

24. Amital H, Arnson Y, Chodick G, Shalev V. Hepatotoxicity rates do not differ in patients with rheumatoid arthritis and psoriasis treated with methotrexate. Rheumatology 2009; 48:1107_10.

25. Burton MJ, Curtis JR, Yang S, Chen L, Singh JA, Mikuls TR et al. Safety of Biologic and Nonbiologic Disease-modifying Antirheumatic Drug Therapy in Veterans with Rheumatoid Arthritis and Hepatitis C Virus Infection. J Rheumatol. 2017 May,44:565-570.

26. Tang KT, Chen YH, Lin CH, Chen DY. Methotrexate is not associated with increased liver cirrhosis in a population-based cohort of rheumatoid arthritis patients with chronic hepatitis C. Sci Rep. 2016,6:33104.

27. Singh JA, Saag KG, Bridges SL Jr, Akl EA, Bannuru RR, Sullivan MC, et al. 2015 American College of Rheumatology guideline for the treatment of rheumatoid arthritis. Arthritis Rheumatol 2016,68:1-26

28. Pritchard C. Etanercept and hepatitis C. J Clin Rheumatol 1999,5:179.

29. Brunasso AM, Puntoni M, Gulia A, Massone C. Safety of anti-tumour necrosis factor agents in patients with chronic hepatitis C infection: a systematic review. Rheumatology 2011,50:1700-11

30. United States FDA. Safety alerts for drugs, biologics medical devices, and dietary supplements. Remicade (infliximab). Washington DC: FDA, 2004. http://www.fda .gov/Safety/MedWatch/SafetyInformation/ SafetyAlertsforHumanMedicalProducts/ucm166901.htm

31. Iannone F, La Montagna G, Bagnato G, Gremese E, Giardina A, Lapadula G. Safety of etanercept and methotrexate in patients with rheumatoid arthritis and hepatitis $\mathrm{C}$ virus infection: a multicenter randomized clinical trial. J Rheumatol. 2014,41:286-92

32. Lin KM, Cheng TT, Lin JC, Chen CJ. Tumor necrosis factor-a antagonist therapy for concomitant rheumatoid arthritis and hepatitis C virus infection: a case series study. Clin Rheumatol. 2015,34:1039-46.

33. Pompili M, Biolato M, Miele L, Grieco A. Tumor necrosis factor-a inhibitors and chronic hepatitis C: a comprehensive literature review. World J Gastroenterol. 2013,19:7867-73. 
34. Chen YM, Chen HH, Chen YH, Hsieh TY, Hsieh CW, Hung WT et al. A comparison of safety profiles of tumour necrosis factor a inhibitors and rituximab therapy in patients with rheumatoid arthritis and chronic hepatitis C. Ann Rheum Dis. 2015,74:626-7.

35. Gandhi NP, Manadan AM, Block JA. Retrospective Study of Patients on Etanercept Therapy for Rheumatic Diseases in Patients With Chronic Hepatitis C Virus. J Clin Rheumatol. 2017,23:252-257

36. Temel T, Cansu DÜ, Korkmaz C, Kasifoglu T, Özakyol A. The long-term effects of anti-TNF-a agents on patients with chronic viral hepatitis C and B infections. Int J Rheum Dis 2015,18:40-5

37. Ghavami S, Hashemi M, Kadkhoda K, Alavian SM, Bay GH, Los M. Apoptosis in liver diseases - detection and therapeutic applications. Med Sci Monit 2005,11:RA337-45

38. Calabrese LH, Zein N, Vassilopoulos D. Safety of antitumour necrosis factor (anti-TNF) therapy in patients with chronic viral infections: hepatitis C, hepatitis B, and HIV infection. Ann Rheum Dis 2004,63:ii1824.

39. Tsai SL, Liaw YF, Chen MH, Huang CY, Kuo GC. Detection of type 2-like T-helper cells in hepatitis C virus infection: implications for hepatitis C virus chronicity. Hepatology. 1997,25:449-58

40. Zein NN, Etanercept Study Group. Etanercept as an adjuvant to interferon and ribavirin in treatment naive patients with chronic hepatitis $\mathrm{C}$ virus infection: a phase 2 randomized, double-blind, placebo-controlled study. J Hepatol. 2005;42:315-22

41. Roccatello D, Baldovino S, Rossi D, Giachino O, Mansouri M, Naretto C, et al. Rituximab as a therapeutic tool in severe mixed cryoglobulinemia. Clin Rev Allergy Immunol. 2008,34:111-7.

42. Lin KM, Lin JC, Tseng WY, Cheng TT. Rituximab-induced hepatitis C virus reactivation in rheumatoid arthritis. J Microbiol Immunol Infect. 2013,46:65-7.

43. Oldfield V, Dhillon S, Plosker GL. Tocilizumab: a review of its use in the management of rheumatoid arthritis. Drugs 2009,69:609-32

44. Forestier E, Pasquali JL. Long-term safety of tocilizumab treatment on chronic active hepatitis C in a patient with adult onset Still's disease. Joint Bone Spine. 2015,82:136-7

45. Nagashima T, Maruyama A, Kamata Y, Minota S. Unchanged serum viral load and liver function during tocilizumab treatment in a patient with rheumatoid arthritis and hepatitis $\mathrm{C}$ virus infection. Rheumatol Int. 2012,32:2231-2.

46. Iebba F, Di Sora F, Tarasi A, Leti W, Montella T, Montella F. Case report: safety and efficacy of tocilizumab in a patient with rheumatoid arthritis and chronic hepatitis C. Case Rep Med. 2012 doi: $10.1155 / 2012 / 212381$. 
47. Dragonas C, Ehrenstein B, Fleck M. Tocilizumab treatment in a patient suffering from rheumatoid arthritis and concomitant chronic hepatitis C infection. Rheumatology (Oxford) 2012,51:1520-1.

48. Mori S, Fujiyama S. Comment on: tocilizumab treatment in a patient suffering from rheumatoid arthritis and concomitant chronic hepatitis C infection. Rheumatology 2012,51:2300-2.

49. Giannitti C, Fineschi I, Frediani B, Fioravanti A, Galeazzi M. Efficacy and safety of tocilizumab combined with cyclosporine $\mathrm{A}$ in a patient with rheumatoid arthritis and concomitant chronic hepatitis $\mathrm{C}$ virus infection. Clin Exp Rheumatol 2013,31:816.

50. Nakagawa H, Maeda S, Yoshida H, Tateishi R, Masuzaki R, Ohki T et al. Serum IL-6 levels and the risk for hepatocarcinogenesis in chronic hepatitis C patients: an analysis based on gender differences. Int J Cancer. 2009,125:2264-9

51. Mahajan TD, Hooker R, Maher L, Brown G, Reimold A. Abatacept therapy for rheumatoid arthritis in the setting of hepatitis C infection. J Clin Rheumatol 2010,16:332-4

52. Rivellese F, Lobasso A, Barbieri L, Liccardo B, De Paulis A, Rossi FW. Novel therapeutic approaches in Rheumatoid Arthritis: Role of Janus Kinases Inhibitors. Curr Med Chem. 2018 doi: $10.2174 / 0929867325666180209145243$.

53. Turan S, Walker S. Janus Kinase Inhibitors for the Treatment of Rheumatoid Arthritis. Hosp Pharm. 2017 Nov, 52:667-668

54. Boor PPC, de Ruiter PE, Asmawidjaja PS, Lubberts E, van der Laan LJW, Kwekkeboom J. JAK-inhibitor tofacitinib suppresses interferon alfa production by plasmacytoid dendritic cells and inhibits arthrogenic and antiviral effects of interferon alfa. Transl Res. 2017,188:67-79

55. Giner Galvañ V, Oltra MR, Rueda D, Esteban MJ, Redón J. Severe acute hepatitis related to hydroxychloroquine in a woman with mixed connective tissue disease. Clin Rheumatol. 2007,26:971-2

56. Ohtani T, Hiroi A, Sakurane M, Furukawa F. Slow acetylator genotypes as a possible risk factor for infectious mononucleosis-like syndrome induced by salazosulfapyridine. Br J Dermatol. 2003,148:1035-9.

57. Soejima M, Kawaguchi Y, Hara M, Kamatani N. Prospective study of the association between NAT2 gene haplotypes and severe adverse events with sulfasalazine therapy in patients with rheumatoid arthritis. J Rheumatol. 2008,35:724.

58. Jobanputra P, Amarasena R, Maggs F, Homer D, Bowman S, Rankin E et al. Hepatotoxicity associated with sulfasalazine in inflammatory arthritis: A case series from a local surveillance of serious adverse events. BMC Musculoskelet Disord. 2008,11:48. 
59. Inoue K, Sekiyama K, Yamada M, Watanabe T, Yasuda H, Yoshiba M. Combined interferon alpha2b and cyclosporin A in the treatment of chronic hepatitis C:controlled trial. J Gastroenterol. 2003,38:567-72.

60. Galeazzi M, Bellisai F, Manganelli S, Morozzi G, Sebastiani GD. Cyclosporine A for the treatment of autoimmune disorders in HCV infected patients. Autoimmun Rev. 2006,5:493-8.

61. Chandran V, Schentag CT, Gladman DD. Reappraisal of the effectiveness of methotrexate in psoriatic arthritis: results from a longitudinal observational cohort. J Rheumatol. 2008,35:469-71.

62. Visser K, van der Heijde DM. Risk and management of liver toxicity during methotrexate treatment in rheumatoid and psoriatic arthritis: a systematic review of the literature. Clin Exp Rheumatol. 2009,27:101725.

63. Beyeler C, Reichen J, Thomann SR, Lauterburg BH, Gerber NJ. Quantitative liver function in patients with rheumatoid arthritis treated with low-dose methotrexate: a longitudinal study, $\mathrm{Br} \mathrm{J}$ Rheumatol. 1997,36:338-44

64. Salliot C, van der Heijde D. Long-term safety of methotrexate monotherapy in patients with rheumatoid arthritis: a systematic literature research. Ann Rheum Dis. 2009.68:1100-4.

65. Sokolove J, Strand V, Greenberg JD, Curtis JR, Kavanaugh A, Kremer JM et al. CORRONA Investigators. Risk of elevated liver enzymes associated with TNF inhibitor utilisation in patients with rheumatoid arthritis. Ann Rheum Dis. 2010,69:1612-7.

66. Taylor WJ, Korendowych E, Nash P, Helliwell PS, Choy E, Krueger GG et al. Drug use and toxicity in psoriatic disease: focus on methotrexate. J Rheumatol. 2008,35:1454-7.

67. Alcorn N, Saunders S, Madhok R. Benefit-risk assessment of leflunomide: an appraisal of leflunomide in rheumatoid arthritis 10 years after licensing. Drug Saf. 2009,32:1123-34.

68. Jazwinski AB, Jezsik J, Ardoin SP, McCallum RM, Tillmann HL. Etanercept treatment to enable successful hepatitis C virus clearance in a patient with rheumatoid arthritis. Gastroenterol Hepatol (N Y). 2011,7:7724.

69. Roux CH, Brocq O, Breuil V, Albert C, Euller-Ziegler L. Safety of anti-TNF-alpha therapy in rheumatoid arthritis and spondylarthropathies with concurrent B or C chronic hepatitis. Rheumatology (Oxford). 2006,45:1294-7.

70. Fleischmann RM. Safety of biologic therapy in rheumatoid arthritis and other autoimmune diseases: focus on rituximab. Semin Arthritis Rheum. 2009,38:265-80. 
71. Varisco V, Viganò M, Batticciotto A, Lampertico P, Marchesoni A, Gibertini P et al. Low Risk of Hepatitis B Virus Reactivation in HBsAg-negative/Anti-HBc-positive Carriers Receiving Rituximab for Rheumatoid Arthritis: A Retrospective Multicenter Italian Study. J Rheumatol. 2016,43:869-74.

72. Padovan M, Filippini M, Tincani A, Lanciano E, Bruschi E, Epis O et al. Safety of Abatacept in Rheumatoid Arthritis With Serologic Evidence of Past or Present Hepatitis B Virus Infection. Arthritis Care Res (Hoboken). 2016,68:738-43.

73. Cacoub P, Si Ahmed SN, Ferfar Y, Pol S, Thabut D, Hezode C et al. Long-Term Efficacy of InterferonFree Antiviral Treatment Regimens in Patients With Hepatitis C Virus-Associated Cryoglobulinemia Vasculitis. Clin Gastroenterol Hepatol. 2018 doi:10.1016/j.cgh.2018.05.021.

74. Sise ME, Bloom AK, Wisocky J, Lin MV, Gustafson JL, Lundquist AL et al. Treatment of hepatitis C virus-associated mixed cryoglobulinemia with direct-acting antiviral agents. Hepatology. 2016,63:408-17.

75. Bonacci M, Lens S, Mariño Z, Londoño MC, Rodriguez-Tajes S, Sánchez-Tapias JM et al. Long-Term Outcomes of Patients With HCV-Associated Cryoglobulinemic Vasculitis After Virologic Cure. Gastroenterology. 2018,155:311-315.e6.

76. Sollima S, Milazzo L, Antinori S, Galli M. Direct-Acting Antivirals and Mixed Cryoglobulinemia Vasculitis: Long-Term Outcome of Patients Achieving HCV Eradication. Am J Gastroenterol. 2017,112:1753-1754. 
Table 1. Syntethic and biological DMARDs. Recommendations and reported adverse events in patients with chronic inflammatory arthropaties and hepatitis $\mathrm{C}$ virus infection

\begin{tabular}{|c|c|c|c|}
\hline & Recommendation & $\begin{array}{l}\text { Adverse } \\
\text { events }\end{array}$ & References \\
\hline Hydroxycloroquine & $\begin{array}{l}\text { Generally } \\
\text { considered safe in } \\
\text { patients with } \\
\text { Child-Pugh } \\
\text { classes A and B. it } \\
\text { should be } \\
\text { avoided in Child- } \\
\text { Pugh class C }\end{array}$ & $\begin{array}{l}\text { three cases of } \\
\text { severe acute } \\
\text { hepatitis in } \\
\text { patients } \\
\text { without } \\
\text { underlying } \\
\text { hepatic } \\
\text { disease }\end{array}$ & $\begin{array}{l}\text { Giner } \\
\text { Galvañ V et } \\
\text { al, 2007 } \\
{[55]}\end{array}$ \\
\hline Sulfosalazine & $\begin{array}{l}\text { It should be } \\
\text { avoided in Child- } \\
\text { Pugh class B and } \\
\text { C }\end{array}$ & $\begin{array}{l}\text { Acute liver } \\
\text { injury is } \\
\text { described in } 4 \\
\text { on } 1000 \\
\text { users with } \\
\text { arthritis } \\
\end{array}$ & $\begin{array}{l}\text { "Ohtani T et } \\
\text { al, } 2003 \\
\text { [56] }\end{array}$ \\
\hline $\begin{array}{l}\text { Soejima M et al, } \\
2008 \text { [57] }\end{array}$ & & & \\
\hline $\begin{array}{l}\text { Jobanputra P et al, } \\
2008 \text { [58]" }\end{array}$ & & & \\
\hline Cyclosporine A & $\begin{array}{l}\text { Shown to have } \\
\text { antiviral activity } \\
\text { against HCV. It } \\
\text { should be } \\
\text { considered for } \\
\text { treatment in HCV- } \\
\text { RA patients }\end{array}$ & & $\begin{array}{l}\text { "Inoue } \mathrm{K} \text { et } \\
\text { al, } 2003 \\
{[59]}\end{array}$ \\
\hline \multicolumn{4}{|l|}{$\begin{array}{l}\text { Galeazzi M et al, } \\
2006 \text { [60]" }\end{array}$} \\
\hline Methotrexate & $\begin{array}{l}\text { Not } \\
\text { recommended in } \\
\text { presence of } \\
\text { hepatopathy (all } \\
\text { Child-Pugh class) }\end{array}$ & $\begin{array}{l}\text { The } \\
\text { frequency of } \\
\text { liver damage } \\
\text { varies widely } \\
\text { according to } \\
\text { differences in } \\
\text { sampling, } \\
\text { definitions of } \\
\text { damage, dose } \\
\text { regimens, and } \\
\text { presence of } \\
\text { other risk } \\
\text { factors }\end{array}$ & $\begin{array}{l}\text { "Chandran } \\
\text { V et al, } \\
2008[61]\end{array}$ \\
\hline \multicolumn{4}{|l|}{$\begin{array}{l}\text { Visser K et al, } 2009 \\
\text { [62] }\end{array}$} \\
\hline \multicolumn{4}{|l|}{$\begin{array}{l}\text { Beyeler C et al, } \\
1997 \text { [63] }\end{array}$} \\
\hline Salliot C et al, 2009 & & & \\
\hline
\end{tabular}




\begin{tabular}{|c|c|c|c|}
\hline [64] & & & \\
\hline $\begin{array}{l}\text { Sokolove J et al } \\
2010 \text { [65] }\end{array}$ & & & \\
\hline $\begin{array}{l}\text { Taylor WJ et al, } \\
2008[66] "\end{array}$ & & & \\
\hline Leflunomide & $\begin{array}{l}\text { Not } \\
\text { recommended in } \\
\text { presence of } \\
\text { hepatopathy (all } \\
\text { Child-Pugh class) }\end{array}$ & $\begin{array}{l}\text { Transaminase } \\
\text { elevation } \\
\text { occurs in 5\% } \\
\text { of patients. } \\
\text { Acute hepatic } \\
\text { events } \\
\text { generally } \\
\text { occur within } \\
\text { the first } 6 \\
\text { months of } \\
\text { treatment }\end{array}$ & $\begin{array}{l}\text { Alcorn } \mathrm{N} \text { et } \\
\text { al, } 2009 \\
{[67]}\end{array}$ \\
\hline $\begin{array}{l}\text { Anti-TNF alpha } \\
\text { drugs }\end{array}$ & $\begin{array}{l}\text { Safety profile of } \\
\text { anti-TNF-a agents } \\
\text { in the setting of } \\
\text { HCV infection } \\
\text { appears to be } \\
\text { acceptable. } \\
\text { Etanercept is } \\
\text { recommended by } \\
\text { ACR in HCV } \\
\text { patients } \\
\text { (evidence C) }\end{array}$ & $\begin{array}{l}\text { Only } 2 \text { cases } \\
\text { of confirmed } \\
\text { or probable } \\
\text { HCV liver } \\
\text { disease } \\
\text { worsening } \\
\text { among } 153 \\
\text { patients } \\
\text { treated with } \\
\text { anti-TNF-a } \\
\text { agents }\end{array}$ & $\begin{array}{l}\text { "Zein NN et } \\
\text { al, } 2005 \\
{[40]}\end{array}$ \\
\hline $\begin{array}{l}\text { Jazwinski AB e } \\
2011 \text { [68] }\end{array}$ & & & \\
\hline $\begin{array}{l}\text { Roux CH et al, } \\
2006 \text { [69] }\end{array}$ & & & \\
\hline $\begin{array}{l}\text { Brunasso AMG, } \\
2011 \text { [29]" }\end{array}$ & & & \\
\hline Rituximab & $\begin{array}{l}\text { Rituximab seems } \\
\text { to be safe in } \\
\text { patients with } \\
\text { HCV-related } \\
\text { cryoglobulinemia. } \\
\text { No available data } \\
\text { for RA. Not } \\
\text { recommended for } \\
\text { Child-Pugh class } \\
\text { B-C }\end{array}$ & $\begin{array}{l}\text { possible raise } \\
\text { of viremia } \\
\text { without liver } \\
\text { damage }\end{array}$ & $\begin{array}{l}\text { "Chen YM et } \\
\text { al, } 2015 \\
{[34]}\end{array}$ \\
\hline $\begin{array}{l}\text { Fleischmann R] } \\
\text { al, 2009 [70] }\end{array}$ & & & \\
\hline $\begin{array}{l}\text { Varisco V et al, } \\
2016 \text { [71]" }\end{array}$ & & & \\
\hline Abatacept & $\begin{array}{l}\text { Only } 2+22 \\
\text { reported cases. }\end{array}$ & $\begin{array}{l}\text { Safe in } 2 \text { case } \\
\text { reports }\end{array}$ & $\begin{array}{l}\text { "Mahajan } \\
\text { TD et al, }\end{array}$ \\
\hline
\end{tabular}




\begin{tabular}{|c|c|c|c|}
\hline & $\begin{array}{l}\text { Second-line } \\
\text { therapy awaiting } \\
\text { more data }\end{array}$ & & $2010[51]$ \\
\hline \multicolumn{4}{|l|}{$\begin{array}{l}\text { Padovan M et al, } \\
2016 \text { [72], }\end{array}$} \\
\hline \multicolumn{4}{|l|}{$\begin{array}{l}\text { Burton MJ et al, } \\
2017 \text { [25]" }\end{array}$} \\
\hline Tocilizumab & $\begin{array}{l}\text { Only } 4 \text { reported } \\
\text { cases. Second-line } \\
\text { therapy awaiting } \\
\text { more data }\end{array}$ & $\begin{array}{l}\mathrm{HCV} \\
\text { reactivation } \\
\text { in one case }\end{array}$ & $\begin{array}{l}\text { "Mori S et } \\
\text { al, } 2012 \\
{[48]}\end{array}$ \\
\hline \multicolumn{4}{|l|}{$\begin{array}{l}\text { Dragonas C et al, } \\
2012 \text { [47] }\end{array}$} \\
\hline \multicolumn{4}{|l|}{$\begin{array}{l}\text { Oldfield V et al, } \\
2009 \text { [43] }\end{array}$} \\
\hline \multicolumn{4}{|l|}{$\begin{array}{l}\text { Iebba F et al, } 2012 \\
{[46] "}\end{array}$} \\
\hline $\begin{array}{l}\text { Targeted synthetic } \\
\text { DMARDs }\end{array}$ & $\begin{array}{l}\text { No reported } \\
\text { cases. No } \\
\text { recommendations }\end{array}$ & $\begin{array}{l}\text { Only in-vitro } \\
\text { data }\end{array}$ & $\begin{array}{l}\text { Boor PPC et } \\
\text { al, } 2017 \\
{[54]}\end{array}$ \\
\hline
\end{tabular}


Table 2. Drug-drug interactions between HCV DAAs and DMARDs

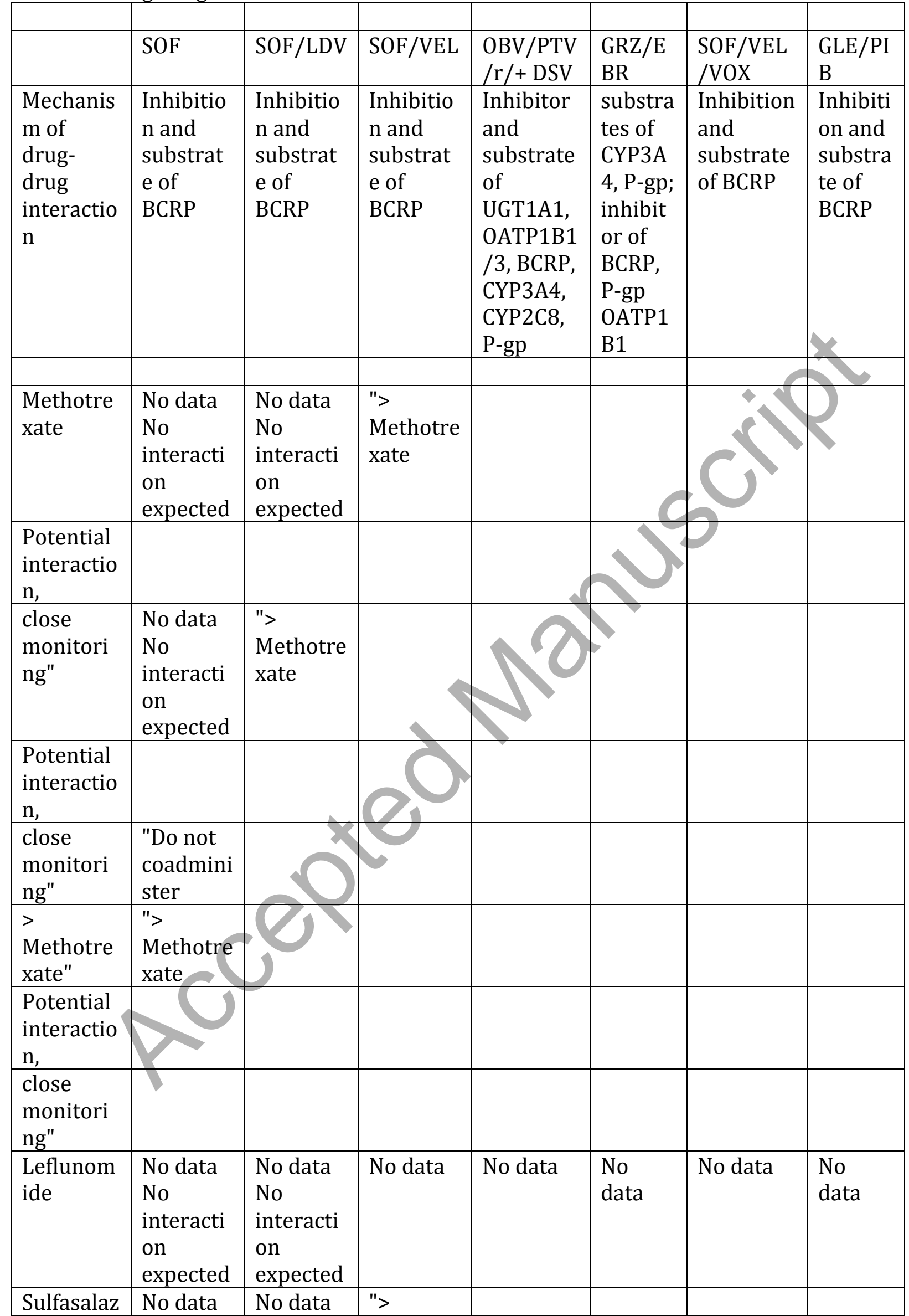




\begin{tabular}{|c|c|c|c|c|c|c|c|}
\hline ine & $\begin{array}{l}\text { No } \\
\text { interacti } \\
\text { on } \\
\text { expected }\end{array}$ & $\begin{array}{l}\text { No } \\
\text { interacti } \\
\text { on } \\
\text { expected }\end{array}$ & $\begin{array}{l}\text { sulfasala } \\
\text { zine, }\end{array}$ & & & & \\
\hline \multicolumn{8}{|l|}{$\begin{array}{l}\text { Potential } \\
\text { interactio } \\
n,\end{array}$} \\
\hline $\begin{array}{l}\text { close } \\
\text { monitori } \\
\text { ng" }\end{array}$ & $\begin{array}{l}\text { "> } \\
\text { sulfasala } \\
\text { zine, }\end{array}$ & & & & & & \\
\hline \multicolumn{8}{|l|}{$\begin{array}{l}\text { Potential } \\
\text { interactio } \\
\text { n, }\end{array}$} \\
\hline $\begin{array}{l}\text { close } \\
\text { monitori } \\
\text { ng" }\end{array}$ & $\begin{array}{l}\text { No data } \\
\text { No } \\
\text { interacti } \\
\text { on } \\
\text { expected }\end{array}$ & $\begin{array}{l}\text { "Do not } \\
\text { coadmini } \\
\text { ster }\end{array}$ & & & & & \\
\hline $\begin{array}{l}> \\
\text { sulfasalaz } \\
\text { ine" }\end{array}$ & $\begin{array}{l}\text { "> } \\
\text { sulfasala } \\
\text { zine, }\end{array}$ & & & & & & \\
\hline \multicolumn{8}{|l|}{$\begin{array}{l}\text { Potential } \\
\text { interactio } \\
\mathrm{n},\end{array}$} \\
\hline \multicolumn{8}{|l|}{$\begin{array}{l}\text { close } \\
\text { monitori } \\
\text { ng" }\end{array}$} \\
\hline $\begin{array}{l}\text { Etanerce } \\
\text { pt }\end{array}$ & $\begin{array}{l}\text { No data } \\
\text { No } \\
\text { interacti } \\
\text { on } \\
\text { expected }\end{array}$ & $\begin{array}{l}\text { No data } \\
\text { No } \\
\text { interacti } \\
\text { on } \\
\text { expected }\end{array}$ & $\begin{array}{l}\text { No data } \\
\text { No } \\
\text { interacti } \\
\text { on } \\
\text { expected }\end{array}$ & $\begin{array}{l}\text { No data } \\
\text { No } \\
\text { interactio } \\
\mathrm{n} \\
\text { expected }\end{array}$ & $\begin{array}{l}\text { No } \\
\text { data } \\
\text { No } \\
\text { interac } \\
\text { tion } \\
\text { expecte } \\
\text { d }\end{array}$ & $\begin{array}{l}\text { No data } \\
\text { No } \\
\text { interactio } \\
\mathrm{n} \\
\text { expected }\end{array}$ & $\begin{array}{l}\text { No } \\
\text { data } \\
\text { No } \\
\text { interac } \\
\text { tion } \\
\text { expecte } \\
\text { d }\end{array}$ \\
\hline $\begin{array}{l}\text { Rituxima } \\
\text { b }\end{array}$ & $\begin{array}{l}\text { No data } \\
\text { No } \\
\text { interacti } \\
\text { on } \\
\text { expected }\end{array}$ & $\begin{array}{l}\text { No data } \\
\text { No } \\
\text { interacti } \\
\text { on } \\
\text { expected }\end{array}$ & $\begin{array}{l}\text { No data } \\
\text { No } \\
\text { interacti } \\
\text { on } \\
\text { expected }\end{array}$ & $\begin{array}{l}\text { No data } \\
\text { No } \\
\text { interactio } \\
\mathrm{n} \\
\text { expected }\end{array}$ & $\begin{array}{l}\text { No } \\
\text { data } \\
\text { No } \\
\text { interac } \\
\text { tion } \\
\text { expecte } \\
\text { d }\end{array}$ & $\begin{array}{l}\text { No data } \\
\text { No } \\
\text { interactio } \\
\mathrm{n} \\
\text { expected }\end{array}$ & $\begin{array}{l}\text { No } \\
\text { data } \\
\text { No } \\
\text { interac } \\
\text { tion } \\
\text { expecte } \\
\text { d }\end{array}$ \\
\hline $\begin{array}{l}\text { Tocilizum } \\
\mathrm{ab}\end{array}$ & No data & No data & No data & No data & $\begin{array}{l}\text { No } \\
\text { data }\end{array}$ & No data & $\begin{array}{l}\text { No } \\
\text { data }\end{array}$ \\
\hline $\begin{array}{l}\text { Abatacep } \\
t\end{array}$ & No data & No data & No data & No data & $\begin{array}{l}\text { No } \\
\text { data }\end{array}$ & No data & $\begin{array}{l}\text { No } \\
\text { data }\end{array}$ \\
\hline $\begin{array}{l}\text { Tofacitini } \\
\text { b }\end{array}$ & No data & No data & No data & No data & $\begin{array}{l}\text { No } \\
\text { data }\end{array}$ & No data & $\begin{array}{l}\text { No } \\
\text { data }\end{array}$ \\
\hline Baricitini & No data & No data & No data & No data & No & No data & No \\
\hline
\end{tabular}


"DAA, direct-acting antiviral; DMARDs, disease modifying antirheumatic drugs; DSV, dasabuvir; EBR, elbasvir; GLE, glecaprevir; GZR, grazoprevir; HCV, hepatitis C virus; LDV, ledipasvir; OBV, ombitasvir; PIB, pibrentasvir; PTV, paritaprevir; r, ritonavir; SOF, sofosbuvir; VEL, velpatasvir; VOX: voxilaprevir, BCRP; breast cancer resistance protein. The symbol (green, amber, red) used to rank the clinical significance of the drug interaction is based on www.hepdruginteractions.org (University of Liverpool)." 